\title{
財団研究論文
}

\section{生活保護受給者自立支援事業における行政と民間との連携 一今後の地域精神保健アウトリーチ支援に必要な技術に関する検討一}

\author{
廣川 聖子 ${ }^{1,2)}$ ，大山早紀子 ${ }^{3)}$ ，大島 䉷 ${ }^{3)}$ ，角田 秋 ${ }^{4)}$, \\ 添田 雅宏 ${ }^{3)}$ ，村嶋 幸代 ${ }^{5)}$ ，萱間 真美 ${ }^{4)}$
}

本研究では、地域医療における精神科未治療・治療中断者等, 治療関係の確立が困難な対象への 訪問支援について, 市町村が行う生活保護受給者への健康管理支援事業における支援内容の分析か ら今後の訪問支援に期待される社会的役割・機能およびそれに対応した今後の専門職への教育のあ り方を検討することを目的とした。

事業の支援対象のうちメンタルヘルス上の問題を有する被保護世帯への訪問支援を実施している 看護師，精神保健福祉士，また事業担当責任者に支援内容に関するインタビュー調查を行い，質的 な分析を行った。

支援員の主たる役割として，看護師は「健康管理」が，精神保健福祉士は「ケアマネジメント」 が特に期待されていたが、訪問支援をより効果的に機能させるためには単一職種ではなく多職種 チームによる包括的支援体制の整備が必要であった。支援対象者は自らは支援を求めておらず, 支援・ 治療関係の構築が困難であり, 支援員はまず支援開始前の関係構築のプロセスに十分な時間を必要 としていた。今後, 民間による訲問支援サービスを発展させていくために, 支援者には関係構築, 家族アセスメント，ケアマネジメント，多職種コーデイネート各スキルの向上が必要であり，専門 職教育においてもこれらの点について学習する機会をもつことが必要であると考えられた。

キーワード アウトリーチ, 関係構築, 未治療・治療中断者, メンタルヘルス

\section{1.はじめに}

近年のわが国の精神保健医療福祉施策において, 「入院医療から地域生活へ」という基本的方策から, 精神科入院病床の削減や安定した地域生活を継続 するための訪問支援システムの整備等の地域精神 医療システムの改革が進められている。実際, 訪

\footnotetext{
1) 聖路加看護大学大学院

2) 埼玉県立大学

3) 日本社会事業大学大学院

4) 聖路加看護大学

5) 大分県立看護科学大学
}

問看護やホームヘルプサービス, $\mathrm{ACT}$ 注 1 等のア トリーチサービス (訪問支援)を利用しながら地域 で生活する精神障害者も増加しており，精神科訪 問看護を利用することにより，入院期間の短縮, 通院継続, 他資源の利用が促進され支援体制が手 厚くなること, 利用していない者に比べ自殺率が

注1) ACT (assertive community treatment)：わが国 では厚生労働省が「包括型地域生活支援プログラ ム」という意訳語をあてており, 従来であれば入院 が必要とされていたような精神障害者に, より自立 的で質の高い地域生活を援助するための, 医師や 看護師, 精神保健福祉士等から成る訪問チームに よる集中的・包括的な医療・福祉プログラムである。 
低いことなどの効果も報告されている（萱間, 2006； 萱間, 2010)。しかし現状では, これらのアウトリー チサービスを受けられるのは精神科治療を受けて おり主治医からの指示が出されていること，本人 もしくは家族から同意が得られていること（契約 の締結）が前提となっている。

一方で, 地域には, 精神科医療・支援の必要性 がありながらそれに結びつかない人びとが存在し, これらの人びとへの支援が昨今の地域メンタルヘ ルス支援に拈いて重大な課題となっている。米国 の調査では, 統合失調症と診断される者のうち少 なくとも $40 \%$ の患者は定期的な支援を受けておら ず，専門的精神医療に関しては50\%もの患者が治 療を受けていなかった（Mojtabai et al., 2009）。 治療中断者については, 統合失調症患者の約 $1 / 3$ が治療開始から 10 年内に治療から脱落している (O’ Brien, Fahmy and Singh, 2009)。わが国では, 不安障害, 気分障害, 物質依存障害の診断がつく 者のうち，過去12ヶ月でサービスを利用した者は， 僅か $20 \%$ 程度にしか及んでいない（Naganuma et al., 2006)。実際にはこの他に, 物質依存や虐待, 引きこもりなど家族内で問題が抱え込まれ，外か ら把握されないまま経過し, 症状悪化などをみて いる未治療・治療中断等の要支援者がさらに多く 存在していると考えられているが，そのような事 例がどのくらい存在するのかといった基礎データ すら，わが国では把握されていない。

このような, 支援の必要性があるにもかかわら ず何らかの阻害要因により自らは医療, 支援など 他者の介入を求めない者については, 従来, 本人 以外の者から相談が持ち込まれることで保健所等 の公的機関によって把握され，保健師らによって 支援がなされてきた。しかし近年，保健師の業務 分担と専門分化が進み，また市町村統廃合による 保健師の異動や担当地区の広域化といった背景か ら，保健師が個別ケースについて細やかに把握し 関わるといった機会は減少してきている（江藤・赤 星・草間, 2009 ; 萱間・新村, 2011)。行政のマンパ
ワーにも限界がある中で，これらの人びとに対し， 生活環境をふまえた症状の見立てを行い，危機介 入レベルに至る前に継続的に支えていくシステム， 当事者だけでは治療やサービス利用の継続が困難 な者への地域での自立・安定した生活を支えるシ ステムが新たに整備される必要があり，公民連携 による柔軟なニーズ対応が, 現在支援から漏れ落 ちる人びとへの支援において有効であると考えら れる。実際に, 積極的な医療・生活支援の目的で, 2011年から民間の医療機関を活用した精神障害者 アウトリーチ推進事業（厚生労働省）も開始され ており，今後は民間の訪問支援サービスにおいて も，契約に基づかない対象への支援技術が新たに 必要とされると考えられる。

本研究では，このように自らでは支援を求めな い要支援者の特徵ならびにそれらの人びとへの効 果的な支援方法を検討する一方法として，地方自 治体が行っている生活保護受給者自立支援事業の 一類型である, “健康管理支援プログラム”に着目 した。わが国では近年, 生活保護受給者（以下, 被保護者）の増加が問題となっているが，厚生労 働省の調査によると, 被保護者においては一般人 口に比べ精神疾患の有病率が高く，平成21年度の データでは $16.4 \%$ と全国平均 $(2.5 \%)$ よりも 6.5 倍も 高いことが指摘されている。また, 自殺率について も64.2 と全国の自殺率 (人口10万対 25 )の 2.5 倍にも 及び，そのうち精神疾患を有していた者は $66.2 \%$ と なっている。このように, 被保護者は何らかの健 康支援・生活支援を必要とする集団であるといえ るが，支援実施内容の実態について明確に示した 資料はみあたらない。

生活保護受給者自立支援事業は, 社会保障審議 会福祉部会「生活保護の在り方に関する専門委員 会」による生活保護制度の見直しに伴い，平成 17 年度から開始された。専門委員会の意見をふまえ, 厚生労働省は「平成17年度における自立支援プロ グラムの基本指針について」（平成17年 3 月 31 日） を示し，各自治体にプログラム策定の具体化を促 
した。それによれば，自立支援プログラムとは， 「実施機関が管内の被保護世帯全体の状況を把握 した上で, 被保護者の状況や自立阻害要因につい て類型化を図り, それぞれの類型ごとに取り組む べき自立支援の具体的内容及び実施手順等を定め, これに基づき個々の被保護者に必要な支援を組織 的に実施するもの」とされている。健康管理支援 プログラムは, メンタルヘルス上の問題により健 康関連行動を含む必要なセルフケアが阻害されて いる受給者に, 生活保護担当ケースワーカー（以 下，生保ワーカー）だけでなく精神保健医療福祉 の専門家との協働で支援を行うことによって自立 を促すものである。現状では, 生活保護担当部署 にメンタルヘルスの専門家が配置されている例は 少なく, 外部委託等によりその多くが実施されて いる。従来の民間の訪問支援サービスとの違いは, 支援対象に未治療・治療中断など, 支援開始時点 では精神科医療を受けておらず，「精神疾患に罹患 している可能性が高い (診断前)」の者も含む点で あり，このプログラムの支援実態について明らか にすることから, 今後の地域精神医療システムに おける有効な訪問看護への示唆を得ることが可能 になると考えた。

今回, 効果的な公民連携のあり方とその課題に ついての検討もふまえ, 今後のアウトリーチ支援 の発展に必要な訪問支援技術およびそれらを獲得 するための教育について検討するための資料を得 ることを目的として，本研究を行った。

\section{2 . 研究対象および研究方法}

\section{1 ) 研究対象}

対象自治体の抽出は, 以下の手順に沿って行った。 (1)厚生労働省社会·援護局保護課「社会·援護局関 係主管課長会議資料 (平成 21 年 3 月 2 日) 」の自 立支援プログラム策定状況・実施状況個別リス トから，下記(2)の条件を満たす自治体を関東圈 から抽出した。

(2)対象自治体は以下の条件を満たすものを選択し
抽出した。

a. リストから, 被保護者のうちメンタルヘル ス上の問題をもつ者への健康管理支援・生活 支援を実施している自治体を全て抜き出す。

b. 抜き出した中から, その事業に携わる職種 の組み合わせ（保健師が含まれるもの，看護 師が含まれるもの, 看護職が含まれないもの) や, 事業運営の方法 (NPOや民間事業所に委 託しているもの, 外部委託していないもの) が 複数のパターンになるように任意に対象自治 体を抽出する。また, 事業の支援内容として, 訪 問による支援を行っていることを条件とする。 (3)抽出した自治体の事業担当者に問い合わせ, 条 件を満たしているか確認し, 該当する場合は調 查協力を得られるか口頭にて確認し, 了承を得 られた場合に対象自治体とした。

以上の手順により対象自治体の抽出を試みたと ころ, リスト上ではプログラムが策定されていて も, 該当ケースの不在, マンパワー不足 (人員不 足・専門職の不在) などにより, 実際に運用され ている自治体は調査時（平成22年）には僅かであ り，実施されている場合でも支援員はケースへの 直接的な支援はしておらず，生保ワーカーのスー パービジョンを主とする内容の自治体もあった。 関東圈からのみでは条件を満たす例が少なかった ことから, 全国にその範囲を広げ, 特に生活保護 受給者が多い地域に注目し抽出を試みた。その結 果, 関西圈の 3 自治体が条件に合致したため, 計 5 自治体を今回の調査対象自治体とした。対象自 治体で実施されている生活保護受給者自立支援事 業のうち, 健康管理支援に係るプログラムに従事 している看護師 2 名（対象者ID：Ns 1, Ns 2), 精神保健福祉士 3 名（対象者ID:PSW 1, PSW 2, PSW 3 ), 事業担当責任者, 担当課長, など10名 （5 自治体）にインタビュー調査を実施した。

\section{2 ）調查期間}

平成 22 年 10 月 11 月 


\section{3）デー夕収集}

対象自治体で策定・実施している生活保護自立 支援事業・健康管理支援プログラムに関して, 事 業担当責任者およびプログラムに従事している支 援員 (以後, 研究対象者) に半構造化面接を行っ た。主な調査項目は, (1)事業についての概要（策 定の経緯, 事業の目的, 事業の対象となる要支援 者, 実施者の資格, 支援内容等)，(2)研究対象者の 属性, (3)事業実施において困難や課題を感じてい る点, 実施により効果を感じている点, 民間事業 所に委託している場合はそのメリット・デメリッ 卜，(4)実際に事業に携わる中で“支援が困難だと 感じた世帯”への支援事例，とした。(4)の支援事 例については, 支援開始時からインタビュー時点 （支援が終結しているケースについては終結時） までの一連の支援内容について語ってもらった。

デー夕収集は, 研究対象者の所属施設内の面接 室等で, 1 自治体につき 1 時間程度のインタビュー を 1 回行った。デー夕は, 事例への支援内容の提 示に関しては，聞き取りの段階で個人が特定され るような情報については伏せた形での提示を依頼 した。インタビューの内容は対象者の同意を得て 録音し, 逐語録を作成した。その際, 逐語録から 要支援者, 研究対象者共に特定されないよう, 固 有名詞はすべて匿名化した。

\section{4）デー夕分析}

本研究の研究デザインは, 内容分析法を用いた 因子探索型の質的帰納的研究とした (Krippendorff and Klaus, 1980)。

まず，3）で挙げた調查項目(1)〜(3)について自 治体ごとに整理した。次に(4)について, “支援が困 難だと感じた世帯”への支援内容について語られ たデータから逐語録を作成し，具体的支援内容に 関連するアイテムを抽出し, 語りの前後の文脈を ふまえながら類似する意味内容をもつものを集め たカテゴリごとにその内容を簡潔に表現する概念 ラベルをつけた。それらの支援内容について, 調
査項目 (1)〜 (3)との関連性をふまえ質的な整理・分 析を行った。具体的な手順の一例を示すと, 「… の日に訪問に行った時の話の中で, お酒もたばこ もやめたい，というふうなことをおっしゃったの で,これがいいきっかけだから，もうこの祭しっか り入院して,たばこもお酒もやめたらどう? とかっ て言ったら,“わかりました”という形で...」という 語りに『本人の “なりたい自分”を切り口にした医 療・福祉サービスの提案・導入』というサブカテ ゴリ名を付けた。各研究対象者の逐語録が完成す る度に同様の作業を行い, 類似するサブカテゴリ を集め,【社会資源の情報提供・導入】という概念ラ ベルをつけた。同様の作業を繰り返し, 各研究対 象者から語られた「本人へのケア」「家族へのケア」 に該当する内容を抽出・整理し, 職種別や事業運 営の方法別に比較・分析を行った。

\section{5 ）倫理的配慮}

対象自治体の研究候補者（事業担当責任者なら びに支援員）に，文書を用い口頭にて，研究の目 的, 方法について説明し, 同意が得られた場合に 研究対象者とした。なお, 本研究は, 聖路加看護 大学倫理審査委員会の承認を得て実施した（承認 番号 : 09-088)。

\section{3. 結果}

\section{1 ）生活保護受給者健康管理支援事業および支援 員の概要}

今回対象とした 5 自治体における事業実施要綱 の内容および支援員の属性について, 表 1 に示し た。健康管理を事業の一義的目的として掲げてい る自治体（A，B市）ではいずれも看護師 1 名を 雇用しており，また外部委託ではなく非常勤雇用 という形態をとっていた。生活の自立が一義的目 的となっている自治体（C， D, E市）ではいず れも精神保健福祉士が雇用されており, 事業を民 間事業所へ委託し委託派遣という形態で精神保健 福祉士を 1 名準職員として雇用している例が 2 自 
表 1 事業および支援員の概要

\begin{tabular}{|c|c|c|c|c|c|}
\hline & A市 & B市 & C市 & D市 & E市 \\
\hline 事業名 & $\begin{array}{l}\text { 自立支援プログラム } \\
\text { 健康管理支援事業 }\end{array}$ & $\begin{array}{l}\text { 被保護者健康管理 } \\
\text { 自立支援事業 }\end{array}$ & 健康管理支援事業 & $\begin{array}{l}\text { 被保護者等居宅生活 } \\
\text { 安定化支援事業 }\end{array}$ & $\begin{array}{l}\text { 被保護者居宅生活 } \\
\text { 安定化支援事業 }\end{array}$ \\
\hline 目的 & $\begin{array}{l}\text { 対象者の健康管理を促進 } \\
L, \text { その自立助長を図る }\end{array}$ & $\begin{array}{l}\text { 保健·生活指導により医 } \\
\text { 療・介護扶助の適正な利用 } \\
\text { 支援を図り, 健康管理の自 } \\
\text { 立, 社会的自立を支援する }\end{array}$ & $\begin{array}{l}\text { 関係機関と連携を図りな } \\
\text { がら, 対象者の日常生活 } \\
\text { 自立, 社会参加, 経済的 } \\
\text { 自立の促進を支援する }\end{array}$ & $\begin{array}{l}\text { 対象者の安定した生活を } \\
\text { 阻害する要因の緩和を図 } \\
り \text {, 自立助長を支援する }\end{array}$ & $\begin{array}{l}\text { 対象者が, 自立して安定 } \\
\text { した居宅生活ができる } \\
\text { う支援する }\end{array}$ \\
\hline 対象 & $\begin{array}{l}\text { (1)医療扶助を適用してい } \\
\text { る被保護者 } \\
\text { (2)療養指導, 健康管理指 } \\
\text { 導が必要と判断される } \\
\text { 被保護者 }\end{array}$ & $\begin{array}{l}\text { 日常生活の健康管理が困 } \\
\text { 難であり, 事業により健 } \\
\text { 康管理自立を促進できる } \\
\text { と見込まれる被保護者 }\end{array}$ & $\begin{array}{l}\text { 生活上支援の必要な精神 } \\
\text { 障害及び知的障害をもつ } \\
\text { 被保護者で, 健康管理が } \\
\text { 困難であることが立阻 } \\
\text { 害要因であると認められ } \\
\text { る者及びその家族 }\end{array}$ & $\begin{array}{l}\text { 被保護者等の中で, 精神 } \\
\text { 疾患が原因で安定した居 } \\
\text { 宅生活が営めないと思わ } \\
\text { れる者で, 原則として支 } \\
\text { 援の同意が確認できた者 }\end{array}$ & $\begin{array}{l}\text { 生活上の課題を抱える精 } \\
\text { 神障害のある被保護者 } \\
\text { で, 支援が必要と認めら } \\
\text { れる者のう, 本人の同 } \\
\text { 意が得られる者 } \\
\text { (原則として薬物及びアルコ } \\
\text { ール依存者は対象としない) }\end{array}$ \\
\hline 実施者 & $\begin{array}{l}\text { 健康管理支援医療 } \\
\text { 扶助指導員（看護師） }\end{array}$ & $\begin{array}{l}\text { 保健師, 看護師, 精神保健 } \\
\text { 福祉士等の保健医療福祉 } \\
\text { の専門知識を有する者 }\end{array}$ & $\begin{array}{l}\text { 保健師, 管理栄養士, 精神 } \\
\text { 保健福祉士等の健医療福 } \\
\text { 祉に専門的知識を有する者 }\end{array}$ & $\begin{array}{l}\text { 保健師·看護師 · 精神保 } \\
\text { 健福祉士・医師等の有資 } \\
\text { 格者 }\end{array}$ & $\begin{array}{l}\text { 精神障害分野におけ行 } \\
\text { 門的な支援を行うことが } \\
\text { できる者 }\end{array}$ \\
\hline 委託形態 & 規定なし & 規定なし & $\begin{array}{l}\text { 適切な事業実施が確保 } \\
\text { できると認められる民間 } \\
\text { 事業者等に派遣委託可 }\end{array}$ & $\begin{array}{l}\text { 実施者の用件を満たす有 } \\
\text { 資格職員を配置している } \\
\text { 事業者に委託可 }\end{array}$ & $\begin{array}{l}\text { 実施者の用件を満たす法 } \\
\text { 人等 }\end{array}$ \\
\hline 年齢・性別 & 40 歳代·女性 & 50 歳代·女性 & 30 歳代 $\cdot$ 男性 & 30 歳代 $\cdot$ 男性 & 40 歳代·女性 \\
\hline 職種 & 看護師（Ns1） & 看護師（Ns2） & 精神保健福祉士(PSW1) & 精神保健福祉士 (PSW2) & 精神保健福祉士 (PSW3) \\
\hline $\begin{array}{l}\text { 医療機関での } \\
\text { 職務経験(年) }\end{array}$ & 9 年 & 4 年 & 2 年 & 4 年 & 6 年 \\
\hline $\begin{array}{l}\text { 行政での } \\
\text { 職務経験 }\end{array}$ & なし & あり & あり & なし & なし \\
\hline $\begin{array}{l}\text { 訪問支援 } \\
\text { 経験年数 }\end{array}$ & 6 年 & 8 年 & 4 年 6 ケ月 & 2 年 9 ケ月 & 3 年 9 ケ月 \\
\hline $\begin{array}{l}\text { 現職での } \\
\text { 経験年数 }\end{array}$ & 5 年 & 4 年 & 2 年 6 ケ月 & 2 年 9 ケ月 & 3 年 9 ケ月 \\
\hline $\begin{array}{l}\text { 現職の } \\
\text { 雇用形態 }\end{array}$ & $\begin{array}{c}\text { 非常勤 } \\
\text { 事業担当 } 1 \text { 名 }\end{array}$ & $\begin{array}{c}\text { 非常勤 } \\
\text { 事業担当 } 1 \text { 名 }\end{array}$ & $\begin{array}{c}\text { 委託派遣 } \\
\text { 事業担当 } 1 \text { 名 }\end{array}$ & $\begin{array}{l}\text { NPO 法人に委託 } \\
\text { (事業自体を包括算定で委託) } \\
\text { 事業担当 } 2.5 \text { 人 / 日 } \\
\text { (複数職種) }\end{array}$ & $\begin{array}{c}\text { 委託派遣 } \\
\text { 事業担当 } 1 \text { 名 }\end{array}$ \\
\hline $\begin{array}{l}\text { 現職の } \\
\text { 勤務形態 }\end{array}$ & 週 4 日 & 週 5 日 & 週 5 日 & 週 5 日 & 週 5 日 \\
\hline
\end{tabular}

治体 (C, E市), 事業そのものを民間事業所に包 括委託し精神保健福祉士 2 名, 臨床心理士, 精神 科医，保健師から成る多職種チームにて事業を実 施している自治体が 1 自治体（D市）であった。 D市では受託事業所と自治体が協働で事業の運用 方法を設定し，自治体が業務内容をモニタリング する方法をとっていた。雇用形態の理由について， A， B， C，E市は雇用にかかるコストと目的遂 行のための費用対効果を考えそれぞれ非常勤・委 託と決めており，A，B市は医療の専門家である 看護師の雇用には非常勤採用の方が有効であり, C， E市は生活自立を促すためケースワーク能力 の高い精神保健福祉士の雇用には委託派遣が有効 であるとの判断に拠っていた。D市は精神科病院 も多くメンタルヘルスの問題を抱える被保護者が
多いという地域特性と, その地域で古くから精神 障害者への訪問看護の支援実績がある事業所が存 在していたという背景から，訪問看護事業所への 包括委託という形態をとっていた。いずれの雇用 形態の場合も, 役所内生活保護担当部署内に支援 員の机を配置し，支援員の活動が生保ワーカーか ら見えるよう，また依頼しやすく協働しやすいよ うな環境の整備が意識されていた。

支援対象は，いずれの自治体も健康問題が日常 生活の自立の阻害要因になっていると自治体側が 判断した被保護者を対象としており, 看護師を配 置している 2 自治体では健康問題の内容は精神疾 患に限定されていなかった。支援の必要性を判断す るのは自治体側であるが, 支援導入に際しての要 支援者の同意の有無については，それを要綱に明 
記している自治体とそうでない自治体がみられた。

主な支援内容は相談業務であるが，“健康管理” を目的に掲げた自治体では健康管理指導や不適当 な受診の確認と適正受診への指導，社会的入院の 解消などの医療支援が主として示されており，“日 常生活の自立”を掲げている自治体ではいずれも 制度・社会資源の活用，家庭訪問，通院同行など, ケースワークや日常生活支援について示されてい た。ケースへの事業実施期間については，いずれ の自治体も 1 年を区切りとしていたが，期限内に 終結するケースは稀であり, モニタリング機能と して設置されている評価会議が定期的に開催され， そこで支援継続と判断され数ヶ年にわたり長期的 に支援を継続しているケースがほとんどであった。

アウトカムはいずれの自治体でも明確に規定さ れておらず，事業運用の際には支援件数・訪問件 数や受診に結びついた件数などのアウトプットを 実績として示していた。支援員のケースロードに ついても規定している自治体はみられなかった。

\section{2 ）支援ケースの特徴}

実際に支援員が訪問支援を行っているケースに ついて，プログラム導入の経緯・ケースの類型・ 支援効果を表 2 に示した。今回“支援が困難な事 例”として語られた 8 ケースには, (1)全てのケー スでプログラム開始時に各種サービスや受診の拒 否がみられる，世帯内で複数の問題を抱えている, 近隣住民など他者との接触を拒否する（ひきこも りの）家族員が存在する, 騒音・居室の污染など の近隣トラブルを起こし社会的に孤立している, という状況があり, (2) 1 例の独居ケースを除く 7 世帯が母子もしくは高齢世帯であった。また, (3)6 ケースで世帯内に精神科未治療・治療中断の世帯 員が存在し, 未治療のケースは統合失調症・物質 誘発性精神病性障害 (疑い含む), 治療中の 2 ケー スはうつ病, という精神医学的状態像を呈し, (4) 身体疾患がある場合も本人・家族に精神疾患があ るために治療が阻害（未治療・治療中断）されて いる，という特徵がみられた。生保ワーカーから 依頼される際には受給世帯内の特定の個人の問題

表2 ケース概要（プログラム導入の経緯）

\begin{tabular}{|c|c|c|c|}
\hline ケース ID & プログラム導入 (対象選定) の経緯 & 援助類型 & アウトカム \\
\hline $\begin{array}{l}\mathrm{A}-1 \\
(\mathrm{Ns} 1)\end{array}$ & $\begin{array}{l}\text { 引きこもりの高齢夫婦世帯。夫に肺がん・精神症状があり寝たきり状 } \\
\text { 態であったが, 高齢者担当の保健師も介入困難で受診につがらず, } \\
\text { プログラム導入となる。 }\end{array}$ & $\begin{array}{l}\text { 未治療；受療支援 } \\
\text { (支援期間－約 } 4 \text { 年, 支援継続中) }\end{array}$ & $\begin{array}{l}\text { 外科入院, 退院後往 } \\
\text { 診·訪問看護導入 }\end{array}$ \\
\hline $\begin{array}{r}\mathrm{A}-2 \\
(\mathrm{Ns} 1)\end{array}$ & 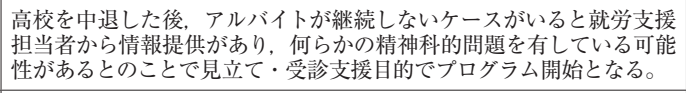 & $\begin{array}{l}\text { 未治療；受療支援 } \\
\text { (支援期間 }- \text { 約 } 2 \text { 支援終結 })\end{array}$ & $\begin{array}{l}\text { 精神科受診 (本人· } \\
\text { 母親), 就労 }\end{array}$ \\
\hline $\begin{array}{l}\mathrm{B}-1 \\
(\mathrm{Ns} 2)\end{array}$ & 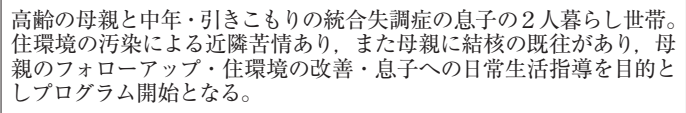 & $\begin{array}{l}\text { 治療中断 ; 安定生活支援 } \\
\text { (支援期間-約 } 1 \text { 年, 支継中) }\end{array}$ & $\begin{array}{l}\text { 健康の維持 }(\text { 本人. } \\
\text { 息子), 息子の行動 } \\
\text { 筙囲拡大 }\end{array}$ \\
\hline $\begin{array}{l}\mathrm{C}-1 \\
(\mathrm{PSW} 1)\end{array}$ & 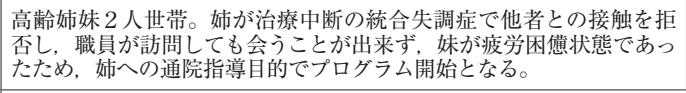 & $\begin{array}{l}\text { 治療中断 ; 受療支援 } \\
\text { (支援期間 }- \text { 約 } 4 \text { 年, 支援継続中) }\end{array}$ & $\begin{array}{l}\text { 精神科医療保護入 } \\
\text { 院 (姉), 世带分離 }\end{array}$ \\
\hline $\begin{array}{l}\mathrm{C}-2 \\
(\mathrm{PSW1})\end{array}$ & 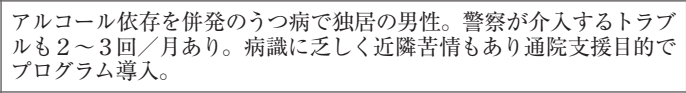 & $\begin{array}{l}\text { 治療中断; 受療支援 } \\
\text { (継続支援期間 }- \text { 約 } 3 \text { 年, 支援継続中) }\end{array}$ & 精神科任意入院 \\
\hline $\begin{array}{l}\mathrm{D}-1 \\
(\mathrm{PSW} 2)\end{array}$ & 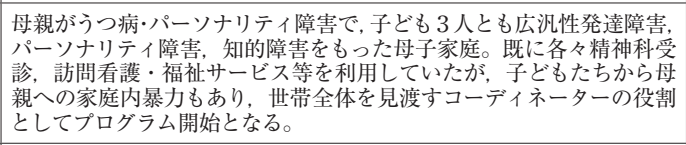 & $\begin{array}{l}\text { 受療中；安定生活支援 } \\
\text { (支援期間 }- \text { 約 } 3 \text { 年, 支拺続中) }\end{array}$ & $\begin{array}{l}\text { 支援機関間の調整, } \\
\text { 新たな社会資源の } \\
\text { 導入, 世带分離 }\end{array}$ \\
\hline $\begin{array}{l}\mathrm{D}-2 \\
(\mathrm{PSW} 2)\end{array}$ & 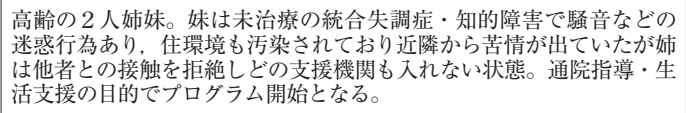 & $\begin{array}{l}\text { 未治療 ; 安定生活支援 } \\
\text { (支援期間 }- \text { 約 } 1 \text { 年, 支援継続中) }\end{array}$ & $\begin{array}{l}\text { 精神科入院 (姉妹), } \\
\text { 住環境の整備 }\end{array}$ \\
\hline $\begin{array}{l}\mathrm{E}-1 \\
(\mathrm{PSW} 3)\end{array}$ & $\begin{array}{l}\text { アルコール依存を併発のうつ病の中年女性。20年以上前に離婚し子ど } \\
\text { も2人との } 2 \text { 人世帝。アルコール依存の入院治療後, クリニックに通 } \\
\text { 院開始となったた通院フォローの目的でプログラム導入となる。 }\end{array}$ & $\begin{array}{l}\text { 受療中 ; 晏定生活支援 } \\
\text { (支援期間 - 約 } 4 \text { 年, 支援継続中) }\end{array}$ & 精神科通院継続 \\
\hline
\end{tabular}


がとりあげられているが，実際に支援員が入って みると世帯全体が支援対象となり，家族アセスメ ントののち, 支援の優先順位が当初と異なり別の 家族員への介入が先行するケースもみられた。

\section{3）支援内容}

ケースへの支援は，基本的には本人からの希望 によるものではないことから, あらかじめ本人・家 族から同意が得られていることは少なく，また他 者の接近に拒否が強い傾向があり, いずれのケー ス・支援員においてもまず支援導入時に「支援員 及び支援を受け入れてもらうための働きかけ」を 必要としていた。実際の支援内容として語られた 内容の一部を資料 1 に示した。本人・家族との関 係構築のため, 拒否されても繰り返し訪問し, 小 さなきっかけを関わりの好機とし，また本人への 直接的な接触だけでなく受け入れのキーマンとな る家族を見極め間接的に支援対象にアプローチす るなど，支援導入の円滑化を図るために種々のス キルが用いられていた。各支援者が行っていた支 援内容について整理したものを，表 3 に示した。 各支援者に共通していた支援としては，ケース本

\section{資料 1 支援員から語られた支援内容の例}

「何回か訪問しているんですけど, やっぱり出て こないんですね。(拒否されても) 根気強く訪 問してみて，またちょっと何回か行ってみて」

(Ns 2)

「無理矢理じゃあ引きこもっている状態のお部 屋をガッと開けるわけにもいかないですし・. (中略) ․゙さこか逃げ道をつくってあげないと， よけいしんどくなるだけなので」

(PSW 1)

「最初入れてくれなかったんだけど, ただ部屋の 中でピーピーと音が鳴っていて，なんか鳴っ ているよね，(僕が) 止めようか？ということで 言っていたら，じゃあ止めてよということで中 に入れてくれて」

(PSW 2)

「もう家庭に入ったら，そこの子どもさんだった りご家族だったりという方を，だいたいほとん どかかわりを持たせてもらって。（刘象は） 1 人だけっていうことではないので」（Ns 1)
人への直接ケアでは【繰り返しの（又は定期的な） 訪問】日常会話を通しての関係作り】な゙があり， その他, Ns 1 は【医療行為を介しての関係作り, 医 学的知識に基づいた説明】という方法によりケース の医療不信の軽減を試み, PSW 2 は【時間を共有し 一緒に悩む】という方法によりケースと互いに理解 し合えるよう意識した働きかけを行っていた。ま た, 生保ワーカーが挙げた顕在化している問題へ の直接的介入以前に, 問題に介入しやすくするた めの環境調整や, 家族との相互関係の中で潜在し ている問題を把握し支援の優先順位を柔軟に変更 する，世帯・環境全てを見渡した上で必要な社会 資源を組み入れた支援体制を見立てる，などの介 入を行っていた。世帯員各者の抱える問題に対し 活用可能なより多くのリソースを取り入れることは 精神保健福祉士に特徴的であった（PSW 1，2) が, 活用しているリソース全体を把握しマネジメン トしていたのはPSW 2 のみであった。背景として, 今回の対象自治体ではPSW 2 のみが多職種チーム の一員として本事業に携わっており，また受託事 業所内の訪問看護ステーション部門との連携も取 りやすい環境にあったことから, 多職種連携とい う意識が他自治体の支援員より強い様子が窥えた。 その他，直接的にはケースに関する支援ではない が, 支援員が自らを機能しやすくするために,【他機 関／他職種との連携・連絡調整】自身が活用でき る地域ネットワークづくり】など, 特にPSW 1,2 で意識的に地域資源との連携体制づくりが日常的 に行われていた。雇用形態別には非常勤雇用型 (Ns 1,2), 自治体·事業所のコラボレート型 (PSW 2) の支援員に比べ, 委託派遣型 (PSW 1，3) では自 身の立場を “生保ワーカーの補助” と意識していた が, 事業以前に行政での勤務経験があったPSW 1 は生保ワーカーと上手く協働して支援にあたって おり, PSW 3 は生保ワーカーや保健所保健師など 他行政職員との関係のとりづらさを感じている様 子が窅えた。 
表 3 支援員による支援内容

\begin{tabular}{|c|c|c|}
\hline 対象 & 支援項目 & 支援内容 \\
\hline \multirow{7}{*}{ 本人 } & 関倸構築（ジョイニング） & 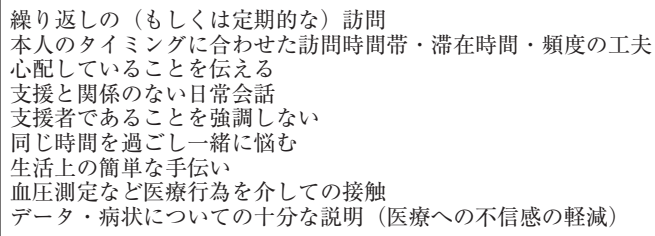 \\
\hline & 情報収集・観察 & $\begin{array}{l}\text { 生活状況・環境・病状確認 } \\
\text { 社会資源の利用状況の確認 } \\
\text { 家族との関係性, 本人の慁族への思いの確認 } \\
\text { 本人の希望の確認 }\end{array}$ \\
\hline & アセスメント & $\begin{array}{l}\text { 病状（精神・身体状況）およびセルフケアのアセスメント } \\
\text { 強みのアセスメント } \\
\text { 必要な社会資源のアセスメント } \\
\text { 家族との相互作用についのアセスメント } \\
\text { 受診の要否・受診阻害要因のアセスメント } \\
\text { 支援終結の見立て (支援目標の設定) }\end{array}$ \\
\hline & 日常生活支援・指導 & $\begin{array}{l}\text { 家事を一緒にやってみる, やり方を教える } \\
\text { 他支援者との関係調整 }\end{array}$ \\
\hline & 社会資源の情報提供・導入 & 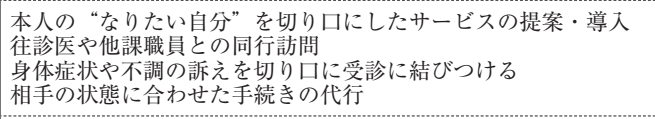 \\
\hline & 入院・通院時の付き添い，入院中の訪問 & 通院同行, 入院時付き添い·手続き, 入院中の病院訪問 \\
\hline & 自宅外での対応 & 来所相談, 電話相談 \\
\hline \multirow{6}{*}{ 家族・世帯 } & 関係構築 & 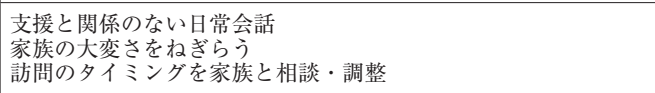 \\
\hline & 情報収集・観察 & $\begin{array}{l}\text { 世帯の生活状況・環境確認 } \\
\text { 家族関係・本人に対する確認 } \\
\text { 思族の支援ニーズ (現状の支援状況) の把握 } \\
\text { 家族の希望の確認 }\end{array}$ \\
\hline & アセスメント & 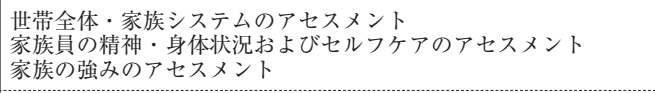 \\
\hline & 情報提供・教育的支援 & $\begin{array}{l}\text { 本人の病状についての十分な説明，関わり方のアドバイス } \\
\text { 本人と接し方についてのアドイス }\end{array}$ \\
\hline & $\begin{array}{c}\text { 社会資源の導入, } \\
\text { 世帯全体を見渡したケアマジメント }\end{array}$ & $\begin{array}{l}\text { 世帯全体を見渡しての支援のターゲッティング (優先順位) } \\
\text { 世帯内の問題それぞれに有効な資源を提案・導入 }\end{array}$ \\
\hline & 自宅外での対応 & 来所相談, 電話相談 \\
\hline
\end{tabular}

注）語られた内容のうち,ケースへの支援に直接的に関係していない内容は省略した。

\section{$4 ）$ 事業実施による効果および課題}

事業実施による効果と課題について, 事業責任 者（担当係長・スーパーバイザー）ならびに支援員 に聞き取りを行った。効果については, 看護師を配 置している自治体 (A，B市) ではいずれも，“相談 対応時に被保護者の病名や服用している薬など医 学的情報をタイムリーに得られること”を挙げて いた。支援員の職種を問わず挙げられた効果は, “生保ワーカーとの同行訪問やスーパービジョン により，関わりが困難な被保護者への対応・ケア コーディネートのモデルが示されること”, “精神
症状等について生保ワーカーでは判断できない専 門的なアセスメントができること”等であった。 支援員からは“支援員の活動に興味を持ち，一緒 に問題に取り組んでくれる生保ワーカーが増えた” という意見も聞かれた。なお，これらの効果につ いては, いずれの自治体でも事業のアウトカムと して測定・評価されてはいなかった。

課題としては，生活自立を一義的目的としてい た自治体では，“医療の視点の不足，医学的見立て の必要性”が挙げられた。具体的には, 未治療・治 療中断のケースについては受診の要否の判断，既 
に医療サービスを利用しているケースについては 就労支援等にステップアップしてよい状態か否か, 自傷他害のリスクアセスメント，といった医学的 視点に基づいた判断, 服薬指導など, 精神保健福 祉士では判断が難しい内容について，医療の専門 家の助言が必要であり, 訪問支援の担当として看 護職や医師が常駐する必要性を挙げていた。また, 受託により業務にあたっている支援員からは，委 託事業であることから毎年同じ事業所 (支援員) が 委託を受けるとは限らず, 他者との関係構築に困 難を抱えるケースへの “支援の継続性”, “支援者交 代に伴う治療・支援からの脱落の可能性”につい て懸念される，との意見も聞かれた。さらに，事 業の運用形態にかかわらず，いずれの自治体もア ウトカムについては支援件数を成果評価としてい たが，“支援の質をどのように評価していくか”が 課題となっていた。

\section{4. 考察}

今回，自治体で実施されている「生活保護受給 者健康管理支援プログラム」を取り上げ，精神科 未治療・治療中断等, 治療関係の構築に困難があ る対象への訪問支援の実態について明らかにし， 効果的な公民連携のあり方とその課題についての 検討を行った。また，その内容をふまえ，今後の アウトリーチ支援に必要な専門職教育のあり方に ついても検討した。

\section{1）地域メンタルヘルス領域における効果的なア} ウトリーチ

\section{（1）多職種チームによる包括的アウトリーチ}

今回の調查対象のうち, D市では精神保健医療 福祉の多様な専門職が混在した多職種チームによ り支援を行っていた。だが実質的には精神保健福 祉士が主な役割を担っており, 医師・看護職といっ た医療の専門家は常駐しておらず，医学的知識が 必要とされる緊急時の判断・対応には困難を感じ ていた。幸い，受託先である事業所は訪問看護ス
テーションを併設しており，医療面での対応は訪 問看護師との連携が柔軟に行われていた。

地域では, 医療導入の緊急度が高い対象への支 援だけでなく，既に医療につながっているが何ら かのサポートがなければ治療の継続が困難である 者や，治療が必要なレベルではないが自立して日 常生活を送ることが困難な者等についても何らか の支援が必要である。この場合，日常生活面での 支援を主としながら医療の視点からもサポートが 可能な, 保健医療福祉の包括的な支援体制が有効 となる。また個人・世帯を包括的にとらえた上で のケアマネジメントもパッケージされた支援が有 効である。現在，アウトリーチ型支援の主力であ る訪問看護については診療報酬上, ステーション への精神保健福祉士の配置が規定されておらず, 独立型のステーション注2) ではケアマネジメント の要素も含む支援には困難さがあると考えられる。 日常的にケアマネジメントの視点を持ちながら訪 問看護を提供している看護師は現状ではそれほど 多くはない。また，他機関と訪問日時を調整しな がらでは，タイムリーな支援をケースに届けるこ とが難しく，また日常的な共通理解の不足から， 支援者内でアセスメントにずれが生じたり，統一 性のない支援となる危険性がある。そのため, チー ム内に多職種が所属していることや, 連携・コー ディネート能力の強化を図ることが, アウトリー チ支援においてはより機能的であり，有効である と考えられた。

\section{(2) 訪問による家族支援}

対象の家庭生活環境そのものを支援の場とする ということは，同居者があるケースでは特に，家 族全体を支援の対象とすることでもある（渡辺， 2003）。従来の訪問支援サービスにおいては，いず

注2）病院・診療所等の医療機関による設立ではない訪 問看護ステーションを「独立型訪問看護ステーショ ン」としている。 
れも契約者個人が支援の対象であり，家族支援は 診療報酬の直接の対象とはなっていない。だが実 際家庭に入ると，本人以外の家族員にも多様な問 題があり, 家族の機能不全が本人の病状や治療へ の参加に大きな影響を及ぼしていることも少なく ない。本調查における各支援員も，家族アセスメ ント・家族支援を対象との関係構築や支援プロセ スに反映させていた。このように，個人の課題を 解消するためには，家族を互いに影響し合う 1 つ のシステムとして捉えアプローチする家族システ ム論に基づいたアセスメント・支援の視点が重要 であると考えられる（Hoffman, 1981；遊佐, 1984）。 その際，1 人の支援者が家族全員の支援を行うこ とは困難であり，また家族の問題に巻き込まれる 危険性もある。複数の支援者で各家族員が抱える 種々の課題に柔軟に対応し，それをプライマリ・ ケースマネージャー（チーム・マネージャー）が 統括し, 家族全体の変化を追いながら支援を進め ていく多職種チームアプローチが，家族支援にお いても有効であると考えられた。

\section{2 ）公民連携によるアウトリーチ}

(1) アウトリーチにおける支援導入時の関係構築 の重要性

本調査で支援事例として挙げられたケースでは いずれも, 他者との接触を拒み, 引きこもり, 社 会的にも孤立し, 必要な健康関連行動がとれない というセルフ・ネグレクトの傾向（岸＼cjkstart他，2011） が共通してみられ，これらの特徵である医療・支 援ニーズの無自覚, 支援の拒否から, 支援につい て本人・家族の同意を得る以前の段階からの専門 的な接近技術と関係構築のための十分なプロセス が必要とされていた。これは, 伊藤 (1991) のいう “治療的変化を促進するための必要条件である治 療協力体制の育成のための働きかけ”であるジョ イニングのプロセスにあたり，特に本調査の事業 のように同意が得られていない対象・家族の生活 の場に出向いての支援においては，ジョイニング
は支援導入・継続のために重要となる。また，要 支援者が支援者と相談しながら主体的に自己の健 康管理に取り組むことを意味するアドヒアランス を高めることが，より効果的な治療・支援に結び つくことからも（Kreyenbuhl, Nossel and Dixon, 2009), ジョイニングにより要支援者の主体的な治 療への参加を導くことは非常に重要となる。今回 の調査では，支援員は支援導入時の接近のための 働きかけとして，共通して“拒否されても繰り返 し訪問”し，“支援者であることを強調しない”で “日常的な会話”で互いを少しずつ理解し合い, 掃 除や家電の操作などちょっとした“日常生活上の 困りごとを手助けする”ことなどを通じて，焦ら ず少しずつ関係を変えるタイミングを計っていた。 そのため, 支援導入時には対象の状況をみながら 柔軟に訪問時間帯や滞在時間, 訪問頻度を変えな がら関係構築のプロセスに十分に時間を費やすな ど，契約内容に基づく内容の 1 回の訪問毎に発生 する対価によって経営が支えられている従来の民 間訪問支援サービスでは対応できない支援形態を とることが可能であった。この結果から，公民連 携のアウトリーチシステムを効果的に機能させて いくためには，新たな支援枠組みについての検討 も必要であることが示唆された。

\section{（2）公民相互の支援ノウハウの共有化}

今回の調査から，公民連携による訪問支援は, 専門的技術を要する支援者が，長期間・複数回訪 問という時間的コストをかけてジョイニングに努 めることを可能にし, 支援同意の取得と支援契約 の締結に道を開く点に有益性があると考えられた。 我が国の公衆衛生活動は平成 4 年度 (1992年度) よ り市町村と都道府県の役割について見直しが行わ れ, 平成 6 年 (1994年) 6 月に「地域保健法」が成 立してからは，保健師による家庭訪問事業の多く は市町村に移譲された。未受診・治療中断（未契 約）の精神科患者への働きかけは, 保健所にその 役割が残されたものの，家庭訪問が地区担当制か 
ら業務分担スタイルとなり（江藤ら, 2009）, 世帯 全体を見渡した包括的なケアマネジメントが提供 される機会が損なわれ，また，縦割り事業の隙間 に漏れ落ちる事例が増す結果となった。さらに近 年, 保健師の訪問支援のためのマンパワーやスキ ルの低下も課題の 1 つなっている（荒田, 2010）。 本調査における事業委託の例では, 行政以外の場 で働く精神医療福祉の専門家が, 委託・非常勤の 形態で行政の準職員として位置づけられることに より，支援拒否ケースへのアクセスが可能となっ ていた。現在，一般的な訪問支援には訪問看護， ホームヘルプサービス，ACT等があるが，いずれ も支援開始に際しては本人との契約が前提となっ ており，また支援の継続についても本人の意思に 拠っている。自ら求めない者へは客観的には支援 の必要があっても積極的に支援を提供することが 出来ず，現状では危機的状態に陥った時にようや く行政による緊急的な介入がなされる，という状 況にある。

ここで，公民連携の有益性は，民間の支援者が 本人・家族の同意なしに支援を開始できるという 権限を持てることではなく, 同意を得るための関 係構築に時間と人的コストをかけられることにあ るという点に注意する必要がある。現状では社会 保障の立場からでなければこのような支援システ ムは成り立ち難く, 公民連携による行政的な立場 と民間の自由さを併せ持つアウトリーチチームの 形成によって，危機介入以前の予防的な働きかけ が可能となるのではないかと考えられた。

\section{（3）公民連携のための課題}

今回の調査で取り上げたのは, 生活保護受給者 というセーフティネットにより行政とのつながり をもっていたことから, 支援の対象として把握さ れ得た世帯であった。行政にも把握されていない 者にまで範囲を広げた公民連携による支援システ ムを普及させていくためには, 次のような課題が あると考えられた。まず，要支援対象者の把握方
法であるが，本人からの支援の要請は難しく，家 族, 地域住民, 民生委員, 児童相談所職員や引き こもり地域支援センター職員等の, 本人以外の者 が情報提供者となることが想定され，これが支援 開始の重要な糸口となる。情報提供者が最初のア クセスでつまずくことがないよう，スムーズに支 援が開始できるようなシステムが望ましく, 行政 が空口となりアウトリーチチームに依頼する，ア ウトリーチチーム自体に空口を置く場合は行政が 広報活動を積極的に担う，などの協働体制の整備 が必要であると考えられた。

また，行政の視点からは数值で把握できるアウ トカムが事業評価指標として期待されるが, 支援 件数だけでは支援の質の評価は困難である。支援 件数を重視すれば，受託する支援者はケースロー ドを増やさざるを得ず，支援の質が担保されなく なる危険性もある。モラルハザードを防ぎ，公民 連携のメリットを十分に活かすためにも，具体的 で明確な事業内容（委託契約内容）と評価指標を 規定し，それに基づいたモニタリング，インセン ティブ, ペナルティー等による管理体制を整備す ることも, 重要な課題であると考えられる。

その他, 役所内に民間の支援者が出入りしやす く日常的に顔を合わせ適宜情報共有できる環境づ くりや，会議など定期的な顔合わせの機会を多く 設定するなど，情報が適宜共有化されやすく連携 されやすい工夫も必要であると考えられた。

\section{3 ）新たなアウトリーチ支援展開のために必要な 技術および専門職教育}

「outreach (アウトリーチ)」の原義は，“手を伸 ばすこと”であり，そこから“支援者側が要支援 者の元に出向いて支援を届けること”を指すよう になった。その内容について, 福祉分野ではサー ビスにつなぐ“ケースマネジメント”機能を, 医 療分野では “治療的な介入・健康管理”機能を中 心とした役割が担われてきたが，地域に生活する 要支援者へは，(1)見立て，(2)治療・治療的支援， 
(3)生活支援の 3 つの目的に向けた支援が同時的に 提供されるような, 医療, 福祉, 保健の要素が統 合された，総合的なアプローチが期待される。

訪問支援機能のさらなる発展を目指すには，こ れまでに述べてきた内容をふまえ，今後は以下の 能力が強化されるような教育が望まれる。

\section{(1) 支援導入時の対象・家族との関係構築技術}

繰り返しになるが，現在の訪問支援においては， 基本的に対象は既に契約が結ばれた個人であり， 支援関係の構築が困難な者については対象となっ ていない。それは診療報酬上，契約前の関係構築 のための訪問には時間をとることができないとい う制度上の問題や，またこれまでの対象の自発的 な行動を前提とした施設型支援における医療の考 え方を色濃く反映していることによる。だが今後, 入院治療病床の削減を図っていくにはこれまでの 考え方では支援に限界があり，訪問支援による未 治療・治療中断者等の治療関係未成立の対象への 働きかけが必要とされるようになると考えられる。 そのような対象と接する際，支援者が現場の特殊 性に即したノウハウを修得していないと，本来の 目的を達成するどころか，双方にとってネガティ ブな体験として終わってしまう危険性も高い。こ れまで，特に訪問看護師はこのようなスキル・ノ ウハウを具体的に学習する機会にそしく，基礎教 育・現任教育の場において, 今後重要となること が考えられる。

\section{(2) 家族アセスメント・スキル}

治療関係の構築が困難な対象の生活に参加して いくには，家族システムを含めた生活環境の把握 が必要となる。対象の家族システムを理解するこ とにより，家族内で起こっている問題を直線的因 果律（1つの原因から 1 つの結果が生じるとする 考え方）ではなく，円環的因果律（円環的あるい は循環的に家族の言動が相互作用しあい問題が維 持されているという, ともに原因であり同時に結
果であるとする考え方）の見方でとらえることが 可能となり, 顕在している個人の問題にのみ対症 療法的に支援を行っていくのではなく，終結も視 野に入れた効果的な支援を行っていくことが可能 になると考える。

\section{(3) ケアマネジメント・スキル}

訪問による効果的な生活支援を行っていくには， 医療的支援だけでなく対象・家族が抱える生活上 の困難全てに対応できる能力が必要となる。医療 的問題と生活上の問題は相互に関連しており, 包 括的な支援の提供がなされなければ支援者として 認識してもらうことは難しい。そのため, 対象・ 家族に必要な資源・サービスを的確にアセスメン 卜し, 対象が生活する地域の資源を把握したうえ で支援体制を組み立て導入手続きをふめるような 知識やスキルが必要となる。訪問支援に携わる支 援者が, より対象者の生活にコミットした支援を 提供していくには，これらについても学習する機 会を持つことが重要となると考えられる。

\section{(4) 多職種連携のためのコーディネート・スキル}

多職種・多機関が連携して支援を行っていく際, キーマンとなり協働体制を整えチームを効果的に 運営していくプライマリ・ケアマネージャーの存 在が必要となる。現在，その役割を担っているの は主には，受診している者であれば通院先の精神 保健福祉士，相談支援事業所を利用している者で あればケア・マネージャー, 生活保護受給者であ ればケースワーカーであるが, 誰かがコーディネー トしてくれるのを待つ, という姿勢では夕イムリー な支援を行っていくことは難しい。効果的に支援 者の連携をコーディネートできる調整能力も, 訪 問支援を行っていく支援者には必要なスキルであ り，強化が必要であると考えられる。

\section{5．結論}

今回，自治体が実施する “生活保護受給者健康 
管理プログラム”に着目し，効果的な公民連携の あり方とその課題について検討を行った。またそ の内容をふまえ, 今後のアウトリーチ支援の発展 に必要な保健医療福祉専門職の教育内容について も，併せて検討した。

地域メンタルヘルス支援の領域において，民間 による訪問支援サービスを今後さらに発展させて いくためには, 多職種チームによる保健医療福祉 の包括的な支援体制の整備が必要であり，また支 援の対象をその個人だけでなく家族も含めた“家 族システム”で捉えアセスメントする視点を持つ ことが，より効果的な支援につながると考えられ た。さらにこれまで保健所の支援対象であった， 未治療・治療中断等の治療契約が結ばれていない 支援に拒否的な対象（世帯）への支援を民間で効 果的に行っていくために，支援者はより専門的な 関係構築技術について十分に理解し, 活用してい くことが必要となると考えられた。

これらの内容をふまえ, 訪問支援に携わる者が 今後さらにその活躍の場を拡大していくためには, 基礎・現任教育において, 関係構築, 家族アセス メント, ケアマネジメント, 多職種・多機関コー ディネートの各実践技術についての学習機会を強 化することが必要であると考えられた。

\section{謝辞}

本研究は, 平成 22 年度医療科学研究所委託研究 「精神科地域医療におけるアウトリーチケア提供の 新しいモデル構築に関する研究（主任研究者：萱 間真美)」によるものである。調査にご協力いただ いた各自治体・医療機関の方々に心より御礼申し 上げます。

\section{引用参考文献}

Hoffman L (1981) Foundations of Family Therapy : A Conceptual Framework for Systems Change. New York : Basic Books.

（邦訳 龟口憲治（1986）『家族療法の基礎理論 創始 者と主要なアプローチ』朝日出版社)

Kreyenbuhl J, Nossel IR and Dixon LB (2009) "Disen- gagement From Mental Health Treatment Among Individuals With Schizophrenia and Strategies for Facilitating Connections to Care: A Review of the Literature," Schizophrenia Bulletin, 35 (4) : 696-703.

Krippendorff K and Klaus H (1980) CONTENT ANALYSIS : An Introduction to Its Methodology. Thousand Oaks, CA : Sage Publications.

(邦訳 三上俊治, 椎野信雄, 橋元良明（1989）『メッ セージ分析の技法』勁草書房)

Mojtabai R, Fochtmann L, Chang SW et al. (2009) “Unmet Need for Mental Health Care in Schizophrenia : An Overview of Literature and New Data From a First-Admission Study," Schizophrenia Bulletin, 35 (4) : 679-695

Naganuma Y, Tachimori H, Kawakami N et al. (2006) "Twelve-month Use of Mental Health Services in Four Areas in Japan: Findings from the World Mental Health Japan Survey 2002-2003," Psychiatry and Clinical Neurosciences. 60 (2) : 240-248.

O'Brien A, Fahmy R and Singh S (2009) "Disengagement from Mental Health Services," Social Psychiatry and Psychiatric Epidemiology, 44 (7) : 558-568.

荒田吉彦（2010）『平成21年度日本公衆衛生協会地域保 健総合推進事業 保健所の有する機能, 健康課題に対 する役割に関する研究報告書』

伊藤順一郎（1991）「家族療法におけるジョイニング」『臨 床精神医学』20(7)：1045-1052

江藤真紀, 赤星琴美, 草間朋子 (2009)「保健師の業務裁量範囲の桩大に関する一考察」『看護科学研究』8: 29-33

大井田隆 (2000)「市町村から見た地域保健法施行後の 保健所像」『保健婦雑誌』56 (9)：769-768

萱間真美, 新村順子 (2011)「地域精神保健に打ける保健 師の役割と活動および今日的課題一保健師役割の変 化に焦点をあてて一」『保健の科学』53 (9)：601-605

荁間真美 (2010)「精神科訪問看護のケア内容と効果に 関する研究」『平成 21 年度厚生労働科学研究費補助金 (障害保健福祉総合研究事業) 精神障害者の退院促進 と地域生活のための多職種によるサービス提供のあ り方とその効果に関する研究. 総括·分担研究報告書』 萱間真美 (2006)「精神科訪問看護と急性期病棟におけ る看護業務」『平成 17 年度厚生労働科学研究費補助金 （医療技術評洒総合研究事業）精神科看護における介 入技術の明確化㧍よび評価に関する研究. 総括・分担 研究報告書』

岸恵美子, 吉岡幸子, 野村祥平 他 (2011)「専門職が 関わる高齢者のセルフ・ネグレクト事例の実態と対応 の課題」『高齢者虐待防止研究』7(1)：125-138

西尾雅明 (2010)『ACT入門 : 精神障害者のための包括 型地域生活支援プログラム』金剛出版

福永一郎 (2005)「地域保健法10年民間の役割」『公衆衛 生』 $69(2): 124-127$

宮脇淳（2005）『PPPが地域を変える アウトソーシング を超えて一官民協働の進化形』ぎょうせい 
医療と社会 Vol.22 No.4 2013

遊佐安一郎 (1984)『家族療法入門：システムズ・アプ ローチの理論と実際』星和書店

渡辺裕子 (2003)「援助を拓く家族アセスメント (10) ア ルコール依存症の息子と共依存の母親 援助のために
まず必要なことは？」『コミュニティケア』5 (1)：80-84

連絡先：廣川聖子

piro_s1123@yahoo.co.jp 


\title{
Outreach for People with Mental Health Problems Who are Receiving Public Assistance: Needs of Change in Community Mental Health Outreach Support
}

\author{
Seiko Hirokawa, Ph.D. ${ }^{1,2)}$, Sakiko Oyama, Ph.D. ${ }^{3)}$, \\ Iwao Oshima, Ph.D. ${ }^{3)}$, Aki Tsunoda, Ph.D. ${ }^{4}$, \\ Masahiro Soeda, Ph.D." , Sachiyo Murashima, Ph.D."), \\ Mami Kayama Ph.D. ${ }^{4)}$
}

\begin{abstract}
This study was conducted to examine the support contents of municipality services, in relation to outreach for persons receiving public assistance who are "difficult to engage," such as untreated persons or those who have dropped out of receiving psychiatric services.

An interview was carried out with nurses and psychiatric social workers responsible for outreach support for people with mental health problems who were receiving public assistance. The interview data were qualitatively analyzed.

Clients who had difficulties in engaging interpersonally did not recognize their need for assistance, and it was difficult for health care professionals to establish relationships with them. The professionals identified the need to have sufficient process time to develop relationships with their clients and families before proceeding with their work. As one of the main roles of health professionals, nurses have been expected to provide medical care, and psychiatric social workers have been expected to provide case management. However, more effectiveness was recognized in a team approach than in the single occupational approach.

For developing outreach service using a nongovernment organization in the future, it will be necessary for health care professionals to acquire skills in relationshipbuilding, family assessment, care management and coordination. In addition, education on these skills will become necessary in professional education.
\end{abstract}

Keywords : Outreach service, Skills of interpersonal connecting, Difficult-to-engage, Mental health

\footnotetext{
1) Graduate School of Nursing Research Division, St.Luke's College of Nursing

${ }^{2)}$ Saitama Prefectural University

${ }^{3)}$ Graduate School of Social Welfare, Japan College of Social Work

4) St.Luke's College of Nursing

${ }^{5)}$ Oita University of Nursing and Health Sciences
} 
